\title{
ЭКСПЕРТИЗЫ
}

Карякин В.В.

\section{О МИРОВОМ РЕЙТИНГЕ АНАЛИТИЧЕСКИХ ЦЕНТРОВ}

\begin{abstract}
Аннотация: Настоящая статья посвящена оценке состояния и эффективности работы российских аналитических центров. Не секрет, что аналитическая деятельность, являющаяся важнейшей стратегической компонентой процесса принятия управленческих решений в российском государстве, переживает сегодня системный кризис, в основе которого лежат вполне определенные и объективные причины. О кризисе российской аналитики свидетельствуют данные международных рейтингов, которые, даже несмотря на ангажированность, все же дают объективную картину состояния аналитической деятельности в России и ее аналитического потенциала. Методология исследования базируется на системном, структурно-функциональном и сравнительно-политическом подходах, методах анализа, синтеза, индукции, дедукции, моделирования, экспертных оценок. Установлено, что у российских экспертов и аналитиков зачастую отсутствует чётко обозначенная позиция по исследуемым проблемам. Наблюдается использование устаревшей методологии анализа и прогнозирования политических процессов от текущего состояния без учёта разно направленных сил, действующих в условиях социально-политического хаоса, инициируемого информационными технологиями воздействия на сознание больших масс населения и политических элит стран с несформировавшимися государственными и общественными институтами. Это приводит к поверхностному анализу происходящих событий и ненадёжности прогнозирования развития политической обстановки в проблемных государствах и регионах.
\end{abstract}

Ключевые слова: рейтинг, Россия, аналитическая деятельность, аналитика, международные отношения, общество, Политика, оценка, интересы, ценности.

22 января 2014 г. директор Московского Центра Карнеги Д. Тренин провёл презентацию Всемирного индекса-рейтинга аналитических центров за 2013 г., представленного в докладе доктора Д. Макганна (James McGann), руководителя программы «Аналитические центры и гражданское общество» Университета Пенсильвании. Рейтинг составлен на основе использования следующих критериев:

- способность привлекать и сохранять в составе центров ведущих учёных и аналитиков;

- объём и стабильность финансовой поддержки центров;

- близость к властным структурам, принимающим политические решения;

- $\quad$ количество посещений сайтов, выступлений на слушаниях в органах законодательной и исполнительной власти, брифингов, официальных встреч и консультаций для государственных чиновников и учреждений, количеством проданных книг, распространенных докладов, ссылок на исследовательские и аналитические работы центров в научных и популярных изданиях;

- $\quad$ количество и качество политических рекомендаций и идей, публикаций книг, статей и ин- формационных материалов, интервью в СМИ, число сотрудников центров, назначенных на государственные должности или работающих в качестве консультантов в государственных структурах.

В своём докладе Д. Тренин отметил, что рейтинг 2013 г. основан на анализе деятельности 6826 организаций из 182 стран мира. Было отмечено, что в США насчитывается 1828 центров, в Китае 426 , в Великобритании - 287, в Индии - 268, в Германии - 194 и в России - 122.

По данным составителей рейтинга, первое место в мире занимает американский Институт Брукингса (Brookings Institution), в котором работает ЗБ. Бжезинский. Кроме него, в десятку ведущих аналитических центров мира вошли: Британский Королевский институт международных отношений (Chatham House), американский Фонд Карнеги за международный мир (Carnegie Endowment for International Peace), американский Центр стратегических и международных исследований (Center for Strategic and International Studies), Стокгольмский международный институт исследований проблем мира (Stockholm International Peace Research Institute), 


\section{Международные отношения / International Relations / № 4/2014}

бельгийский Центр Брюген (Bruegen), американский Совет по внешней политике (Council on Foreign Relations), американская корпорация RAND (RAND Corporation), британский Международный институт стратегических исследований (International Institute for Strategic Studies) и американский Международный научный центр имени Вудро Вильсона (Woodrow Wilson International Center for Scholars).

Из российских организаций в общий мировой рейтинг 150 ведущих аналитических центров были включены: Московский Центр Карнеги (28 место), ИМЭМО РАН (32 место), Совет по внешней и оборонной политике (СВОП) (98 место) и МГИМО(У) (100 место).

В разделе 60 ведущих аналитических центров Центральной и Восточной Европы упоминаются следующие российские организации: Московский Центр Карнеги (2 место), ИМЭМО РАН (4 место), МГИМО(У) (5 место), Центр экономических и финансовых исследований и разработок (ЦЭФИР) (6 место), Независимый институт социальной политики (21 место), Институт США и Канады РАН (27 место), Институт Гайдара (32 место), Экономическая экспертная группа (ЭЭГ) (34 место), СанктПетербургский центр гуманитарно-политических исследований «Стратегия» (38 место), Институт по вопросам безопасности и международных исследований (56 место), Институт общественной политики (58 место), Российский совет по международным делам (РСМД) (60 место).

В своём докладе Д. Тренин отметил следующие недостатки, присущие российским аналитическим центрам:

- отсутствие выхода на зарубежную и особенно англоязычную аудиторию при публикации книг и статей в иностранных журналах и выступлениях в СМИ;
- отсутствие регулярной ротации сотрудников российских аналитических центров с правительственными структурами и организациями. Например, при смене американской администрации до 30 сотрудников Института Брукингса переходят в правительственные структуры в качестве советников. При следующей смене администрации прикомандированные сотрудники, обогащенные опытом практической работы и связями, возвращаются к своей деятельности в прежних или других аналогичных организациях;

- приглашенные на работу в российские аналитические центры, в основном отставные чиновники из государственных органов, зачастую лоббируют интересы своих прежних организаций в ущерб объективности и качеству аналитических материалов;

- слабое финансирование российских аналитических центров не позволяет привлекать к работе крупных учёных и ведущих специалистов;

- $\quad$ у российских экспертов и аналитиков зачастую отсутствует чётко обозначенная позиция по исследуемым проблемам. Наблюдается использование устаревшей методологии анализа и прогнозирования политических процессов от текущего состояния без учёта разнонаправленных сил, действующих в условиях социальнополитического хаоса, инициируемого информационными технологиями воздействия на сознание больших масс населения и политических элит стран с несформировавшимися государственными и общественными институтами. Это приводит к поверхностному анализу происходящих событий и ненадёжности прогнозирования развития политической обстановки в проблемных государствах и регионах.

\section{Библиография:}

1. Манойло А.В. «Финиковые революции»: стихия или управляемый хаос?//Международная жизнь. - 2011.-№5. С. 63-78

2. Карпович О.Г. Демократия и демократизация в контексте нового миропорядка // Политика и Общество. - 2013. - 8. - C. 1012 - 1020. DOI: 10.7256/1812-8696.2013.8.9142.

3. Бочарников И.В. О государственной идеологии России // Международные отношения. - 2013. - 1. - C. 22 - 27. DOI: 10.7256/2305-560Х.2013.01.3.

4. Егоров В.Г. Постсоветские независимые государства: поиск формы правления // Международные отношения. 2014. - 1. - C. 31 - 46. DOI: 10.7256/2305-560X.2014.1.9798.

5. Хизриева С.С. Общественная дипломатия во внешней политике Бразилии в период правления Лулы да Силва // NB: Международные отношения. - 2015. - 1. - C. 47 - 54. DOI: 10.7256/2306-4226.2015.1.12617. URL: http://www.enotabene.ru/wi/article_12617.html

6. Бородинов Е.Н. Анализ нормандской встречи и её значение для России // Тренды и управление. - 2014. - 2. C. 117 - 123. DOI: 10.7256/2307-9118.2014.2.12409. 
7. А. Э. Галумов Перспективы публичной дипломатии и имиджа ЕС в России // Международные отношения. - 2012. - 1. - С. $118-127$.

8. Гушер А.И. Экспертная оценка политико-экономической ситуации в Украине // Международные отношения. 2014. - 3. - C. 326 - 331. DOI: 10.7256/2305-560X.2014.3.11815.

9. Манойло А.В. Геополитическая картина современного мира // Национальная безопасность / nota bene. - 2013. 5. - C. 149 - 155. DOI: 10.7256/2073-8560.2013.5.9394.

10. Карпович О.Г. Новый миропорядок и конфигурирование системы международных отношений во внешней политике США // Политика и Общество. - 2013. - 10. - С. 1270 - 1275. DOI: 10.7256/1812-8696.2013.10.10013.

11. Будаев А.В. Основные подходы к использованию «мягкой силы» в интересах реализации внешней политики Российской Федерации // Тренды и управление. - 2014. - 2. - C. 175 - 187. DOI: 10.7256/2307-9118.2014.2.11784.

\section{References (transliterated):}

1. Manoilo A.V. «Finikovye revolyutsii»: stikhiya ili upravlyaemyi khaos?//Mezhdunarodnaya zhizn'. - 2011.-№5. - S. 63-78

2. Karpovich O.G. Demokratiya i demokratizatsiya v kontekste novogo miroporyadka // Politika i Obshchestvo. - 2013. - 8. - C. 1012 - 1020. DOI: 10.7256/1812-8696.2013.8.9142.

3. Bocharnikov I.V. O gosudarstvennoi ideologii Rossii // Mezhdunarodnye otnosheniya. - 2013. - 1. - C. 22 - 27. DOI: 10.7256/2305-560X.2013.01.3.

4. Egorov V.G. Postsovetskie nezavisimye gosudarstva: poisk formy pravleniya // Mezhdunarodnye otnosheniya. - 2014. - 1. - C. 31 - 46. DOI: 10.7256/2305-560X.2014.1.9798.

5. Khizrieva S.S. Obshchestvennaya diplomatiya vo vneshnei politike Brazilii v period pravleniya Luly da Silva // NB: Mezhdunarodnye otnosheniya. - 2015. - 1. - C. 47 - 54. DOI: 10.7256/2306-4226.2015.1.12617. URL: http://www.enotabene.ru/wi/article_12617.html

6. Borodinov E.N. Analiz normandskoi vstrechi i ee znachenie dlya Rossii // Trendy i upravlenie. - 2014. - 2. - C. 117 - 123. DOI: $10.7256 / 2307-9118.2014 .2 .12409$.

7. A. E. Galumov Perspektivy publichnoi diplomatii i imidzha ES v Rossii // Mezhdunarodnye otnosheniya. - 2012. - 1. C. $118-127$.

8. Gusher A.I. Ekspertnaya otsenka politiko-ekonomicheskoi situatsii v Ukraine // Mezhdunarodnye otnosheniya. - 2014. 3. - C. 326 - 331. DOI: 10.7256/2305-560X.2014.3.11815.

9. Manoilo A.V. Geopoliticheskaya kartina sovremennogo mira // Natsional'naya bezopasnost' / nota bene. - 2013. - 5. C. 149 - 155. DOI: 10.7256/2073-8560.2013.5.9394.

10. Karpovich O.G. Novyi miroporyadok i konfigurirovanie sistemy mezhdunarodnykh otnoshenii vo vneshnei politike SShA // Politika i Obshchestvo. - 2013. - 10. - C. 1270 - 1275. DOI: 10.7256/1812-8696.2013.10.10013.

11. Budaev A.V. Osnovnye podkhody k ispol'zovaniyu «myagkoi sily» v interesakh realizatsii vneshnei politiki Rossiiskoi Federatsii // Trendy i upravlenie. - 2014. - 2. - C. 175 - 187. DOI: 10.7256/2307-9118.2014.2.11784. 